\title{
Comparative Study of Profiled School Scheduling Programs in Lithuania
}

\author{
Rita GAIDUKEVIČIENE் \\ Institute of Mathematics and Informatics \\ Akademijos 4, LT-08663 Vilnius, Lithuania \\ e-mail: rita7@takas.lt
}

\author{
Eugenijus KURILOVAS \\ Centre for Information Technologies in Education, Ministry of Education and Science \\ Suvalku 1, LT-01306 Vilnius, Lithuania \\ e-mail: eugenijus.kurilovas@itc.smm.lt
}

Received: January 2005

\begin{abstract}
Solution of the problem of optimal school scheduling is very important to make the work of comprehensive schools more effective. Here the sequence of teaching subjects, regarded as tools, can be changed. One needs to reduce the sum of gaps ("empty" hours) in the teacher schedules. There should be no gaps for students. Different classes are considered as different tasks. The classrooms, including the computer and physics rooms and studies, are the limited resources.

The most difficult example is scheduling of profiled school. Here eleventh and twelfth grade students are choosing several subjects from the list of available ones. This means that each student works by his own schedule. We search for the most convenient feasible schedule. The inconveniences are evaluated by penalty points.

The purpose of the study is to analyze several commercial scheduling programs which are prevalent in Lithuania at the moment and to compare them with existing timetable version of Optimization Department of Lithuanian Institute of Mathematics and Informatics (IMI) from optimal scheduling point of view. Therefore our research object is to study and compare the quality of optimization algorithms of these programs.

One of the tasks is to identify existing commercial scheduling programs which might be right for Lithuanian profiled comprehensive schools.

Another task is to perform the tentative comparison of scheduling programs MIMOSA, aSc Timetables and IMI timetable version from the point of view of quality of optimal scheduling.

We used three stages for study of these programs:

1) scheduling without any confines - it's allowable to consecutively add two equal subjects, the ultimate number of lessons per day is 10 and teachers are working without day offs;

2) reduction of ultimate number of lessons to 9 lessons per day;

3) optimal scheduling of real Vilnius secondary school.
\end{abstract}

Key words: optimal scheduling, timetable, profiled schools. 


\section{Introduction}

\subsection{Optimal School Scheduling Problem}

Everyone makes a schedule to organize his or her own life. Making a schedule for any organized activities, one considers a sequence of tasks and a list of resources. Resources include tools, machines, materials, work force etc. Of course, making a schedule for organization is far more difficult than making a schedule for our everyday life. A failure to make a schedule or devising a wrong schedule can result in delay of a deadline and can cost much of the money.

The example is scheduling of traditional school that is closer to real life tasks. Here the sequence of teaching subjects, regarded as tools, can be changed. One needs to reduce the sum of gaps ("empty" hours) in the teacher schedules. There should be no gaps for students. Different classes are considered as different tasks. The classrooms, including the computer and physics rooms and studies, are the limited resources.

The most difficult example is scheduling of profiled school. Here eleventh and twelfth grade students are choosing several subjects from the list of available ones (for example, 14 from 60). This means that each student works by his own schedule. We search for the most convenient feasible schedule. The inconveniences are evaluated by penalty points.

Traditional School Scheduling

School scheduling is an example of the general scheduling problem. In these schools the study schedules are fixed for each grade. We consider the case where the objective is the number of "empty" hours when the teachers wait for the next scheduled lectures. One calls these hours as "teacher gaps" or just "gaps" for short. We search for such schedules that reduce the sum of teacher gaps considering the schedules of fifth to twelfth class of the comprehensive school. Other factors are school-specific and should be included adapting the software to specific schools.

\section{Constraints}

There are five constraints:

- at any given moment a teacher can deliver only one lesson,

- at any given moment a student can take part at only one lesson,

- no "student gaps" are allowed,

- the "double" lectures (the sequence of two lectures of the same subject) are not allowed (there are some exceptions),

- the number of lecture hours per day is limited.

The corrected schedule of traditional school is optimized using the permutation algorithm. The algorithm follows a general pattern of permutation algorithms related to the Bayesian Heuristic Approach.

Profiled School Scheduling

Application of the permutation algorithm is more difficult, if classes are divided depending on subjects of choice. Here the number of "classes" is greater because the schedules of divided classes of the same grade are different. In addition, classes are divided for some subjects and united for others, as usual. 
In so-called "Profiled Schools" the students of eleventh and twelfth year select, for example, fourteen subjects from sixty available. That means different individual schedules for most of the students. There are no stable student classes anymore. They are replaced by changing "interest groups". The changes happen each hour.

Personal choices of eleventh and twelfth grade students are defined as sets of subjects. Sequences of these subjects and the corresponding class-rooms are defined by the general school schedule.

In this case a new approach is needed for optimal scheduling. An example is the commercial system MIMOSA. The MIMOSA helps to produce feasible schedules by performing corrections, for example, by closing some gaps, and informing about violated constraints and inconveniences. About 50\% of the schedules produced by MIMOSA depend on the human scheduler operating MIMOSA system. Therefore, comparison with other systems is very difficult. In this sense, the MIMOSA and other similar systems can be regarded mainly as "Support Systems."

The objective of the research implemented in the Optimization Department of IMI is to design workable optimization system for profiled school scheduling. In the genuine optimization system a human operator specifies just general objectives and constraints. The schedules, both general and personal, are produced automatically by an optimization system. These schedules may be corrected by an operator considering some additional factors not included in the general objectives and constraints. The human operator can influence the outcome of optimization by choosing initial schedules, too (the optimization results depend on the initial schedules because there is no possibility to obtain exact solutions in a limited time).

\section{A Compromise Solution}

There are no schedules that satisfy all restrictions and personal preferences because they contradict each other as usual. For example, the ministry of education defines a number of rules to be observed, the school teachers and students both prefer schedules without gaps, etc. Thus, the objective is to find the best compromise of conflicting interests.

A compromise solution is reached by defining penalties for violation of constraints and disregarding inconveniences. We search for such schedule that minimizes the total penalty function. Only the "physical" constraint may not be violated: a person cannot be in two places at the same time.

We assume, that all other constraints may be violated, at a price. Both normative and convenience constraints have to be considered in the research.

\section{Convenience Constraints}

The usual factors of inconvenience are:

- teacher gaps;

- student gaps (for eleventh and twelfth grades);

- inconvenient hours;

- inconvenient days;

- inconvenient sequences of lessons. 
IMI Optimal Scheduling Approach for Profiled Schools

The profiled school scheduling algorithms and software implements permutations similar to these of the traditional school. That is only similarity. Important new ideas are developed and implemented considering profiled school scheduling.

The first one is that the schedules should be evaluated including both objective and subjective factors in a balanced way. The theoretical framework of this is the Pareto optimum. Simplest way to obtain Pareto optimal schedule is by assigning some penalty points for deviations from the desirable or feasible conditions.

The total penalty is minimized. In such a case the penalty points represent subjective opinion of people responsible for schedules. Desirable and feasible conditions reflect objective legal and physical factors.

The second new idea is optimization of heuristics by selecting their best parameters. That is achieved in three stages. In the first stage the same trivial permutation heuristics is used as in the traditional schedule. That works if one starts from nearly optimal schedule what is true in traditional schools as usual. In the profiled schools some "globalization" of permutation heuristics is needed.

That is achieved in the second stage by the Simulated Annealing (SA) schedules applied with same fixed parameters. The third fixed parameter is the probability to delete the name of some teacher waiting in the "improvement" queue. In this case one accepts with some small probability schedules with higher penalties so improving convergence. It is easy to notice that the results of SA approach depend on all of three arbitrarily fixed parameters.

In the final stage these parameters are optimized using methods of stochastic global optimization developed in the framework of the Bayesian Heuristic Approach.

Each stage can be involved separately, that makes comparison of their results much simpler. Java implementation presents excellent opportunities to compare different scheduling versions for any interested person.

The first few trials did show the better results as compared with the commercial software MIMOSA that now is used while scheduling Lithuanian profiled schools. However the statistical analysis of different school scheduling methods, algorithms and software systems is a separate important problem to be considered in future.

\subsection{Purpose of the Study}

The purpose of the study is to analyze several commercial scheduling programs which are prevalent in Lithuania at the moment and to compare them with existing IMI timetable version from optimal scheduling point of view. Therefore our research object is study and comparison of quality of optimization algorithms of these programs.

In Chapter 2 we'll try to identify existing commercial scheduling programs which might be right for Lithuanian profiled comprehensive schools.

In Chapter 3 we'll try to perform the tentative comparison of scheduling programs MIMOSA, aSc Timetables and IMI timetable version from the point of view of quality of optimal scheduling. 
The reason for choosing MIMOSA and aSc Timetables is their prevalence in Lithuanian comprehensive schools at the moment. The main reasons for this are:

- the active marketing policy implementing by appropriate software companies in Lithuania;

- these programs are already localized, that is translated to Lithuanian and adopted for specific Lithuanian education features.

We used three stages for study of these programs:

1. Scheduling without any confines - it's allowable to consecutively add two equal subjects, the ultimate number of lessons per day is 10 and teachers are working without day offs.

2. Reduction of ultimate number of lessons to 9 lessons per day.

3. Optimal scheduling of real Vilnius secondary school.

\section{Several Commercial School Scheduling Programs}

\subsection{ActiveTimetable 2003}

ActiveTimetable 2003 is a program for scheduling timetables in a wide range of educational institutions. Its main advantage is full automatic scheduling of even the most complex timetables in a short time. You can schedule several different timetables from the input data, and choose the one best conforming to the requirements of the institution.

The program ensures that lessons of a subject will be spread evenly in the week (e.g., situations, when a class will have several lessons of the same subject in one day, won't occur (unless the user wants that)).

Due to great flexibility, the program can be used in educational institutions of all sorts, including schools working in non-continuous schedule (e.g., on Fridays, Saturdays and Sundays).

The program was designed in order to make the input of data easy and fast. The user interface is convenient and intuitive. Moreover, the process of entering the data is simplified by the Timetable wizard, using which you can build the skeleton of the timetable fast.

Using the program, you can easily print the collective timetable, as well as individual timetables for teachers and classes. Export to HTML allows trouble-free publishing the scheduled timetable on the Net.

The program:

- schedules normal lessons and lessons in which a class is divided into groups;

- schedules blocks of lessons;

- schedules multi-class lessons;

- allows dividing a class into 30 groups;

- spreads lessons of each subject evenly in the week;

- assigns appropriate rooms to lessons; 
- allows setting the maximal number of hours per day for teachers and classes;

- meets even the most sophisticated requirements. For example, teachers can select timeslots, in which they don't want to have lessons; certain rooms can be empty in selected hours;

- prints the collective timetable and individual timetables for classes and teachers;

- allows to export the timetable to HTML.

\subsection{CMIS Scheduler (CCM)}

Facility Scheduler is multi-user and can allow access (secured) to timetables across the school. It can also allow the school to publish its timetables on the Web, either on an Intranet (within the school) or on the Internet (outside the school). So parents could see the pupil's timetables. More than that as it is an event based scheduler that can schedule, not only the school timetable, but events of any sort, such as meetings, seminars, trips and other school events it can be used as a serious resource planner. The Resource Planner enables the school to enter the available resources at a very early stage in the school year and determine the changes that must be made to the curriculum and the timetable in light of resource considerations. The planning matrices allow a user to easily plan the school curriculum, from creating the initial schedule, through assigning teachers and rooms, all the while ensuring the any rules or constraints are not broken. The Resource Planning environment is fully integrated with the timetabling functionality. The Planning matrices give full visibility of all items including total periods, periods scheduled, Block/Class, Teacher, Subject, Preferred and forced room codes along with the period breakdown. They can be oriented in any way the user likes giving multiple views of the data.

Some features:

- colour coding to show blocking and scheduled status;

- ordering of classes, teachers, subjects and rooms controlled by the user;

- multiple planning views;

- scheduling from the planning matrix in the case where a change is made to a scheduled item;

- drag and drop to copy curricular elements from one class to another;

- multi-select items to form blocks;

- drag and drop items to change subject, teacher, class or room;

- set up links where a subject is split between two teachers;

- teachers grouped by subjects taught or subjects grouped by teachers.

- Full block visibility allows the user to see which subjects and teachers are blocked together. Events are moved around the timetable using drag and drop while in the background all limits and restrictions are checked so that once an event is moved the user can be sure that all restrictions and constraints are intact.

- Scheduling examinations. One of the most powerful aspects of the Scheduler is that it is fully calendar-based, catering fully for the changes that may occur in a school's timetable from week to week. The Scheduler is ideally suited to the demands made by the necessity of timetabling in-house assessments and examinations. Since these 
will usually occur within the school term, a scheduling system must have the ability to produce a customised examination schedule for a given week or other period of time.

- Rotations. The calendar-based aspect of the Scheduler also gives the user the functionality necessary to deal with rotations. Students, or groups of students, can be scheduled to take one subject (or set of subjects) for the first term, and a completely different set for the next. The user has complete control over the period of time to be covered by a particular schedule, or group of events, and is in no way limited by traditional concepts of terms or academic years.

- The view of the subject teacher. Each teacher can view his timetable across the network. Security ensures that timetables cannot be altered. A teacher can instantly view his/her timetable and have direct access to the Teaching Group. The teacher can even then drill down to the student timetables and know where they are going for the next class or the rest of the day. A teacher may, using the Switch to function, change to a view of the room if it is in use after the next class and if so who will be using the room. Individual staff members can make temporary room changes in this way.

- Matching pupil attendance, lesson by lesson, against the timetable. The system allows the Form teacher or the Head to report on the absence/truancy rate of individual pupils or pupils in certain categories. Student attendance can be tracked against the actual timetable on a lesson by lesson basis. The school can communicate with Parents/Guardians or with Welfare or Social Security agencies providing precise information on the attendance patterns of pupils. The school can also incorporate this attendance data into the Pupil Profile or the school can obtain a School Profile showing the attendance patterns against the schedule.

- Scheduling schools events. Facility Scheduler allows the school to schedule all sorts of events, such as parents' evenings, sports days, open days and staff improvement days.

\subsection{Cyber-Matrix Class Scheduler}

Cyber-Matrix Class Scheduler is the software ideal for schools and other educational institutions that need to quickly schedule classes. Block scheduling allows the scheduling of groups of students (whole classes) instead of just single students. The database engine has also been replaced for a smaller resource footprint.

Some features:

- Automatic Scheduling: a group of needed classes can be entered and a list of possible schedules can be selected from.

- Block Scheduling: whole groups of students can be scheduled at one time.

- Multi-user: share schedule data over your network for all your students and teachers.

- Searching: a search feature allows for finding all students that take a particular class or that share a common classification, such as band students. 
- Security: when security is enabled students can schedule courses without being able to change the classes of other students.

- Multiple Views: the schedule view allows viewing by class schedule, student schedule, instructor schedule and by classroom schedule.

- Schedule Reports: schedule reports may be viewed for one or many schedules just as they would appear on the screen.

- Customisable Time Period: schedule classes on the hour, half-hour or any other hourly fraction.

- Multi-Language Support: users from non-English speaking countries may easily convert the software's text into their own language's equivalents.

\section{4. iMagic}

iMagic Timetable Master helps you to create timetables for schools, colleges or universities.

Key Features:

- clash free - clashes are detected before they occur;

- auto Fill - save time manually entering information;

- covers using Tutors, Subjects, Rooms, Classes;

- search and Replace entries;

- quick and easy to use - just install and start typing;

- advanced features allowing you to specify subjects taught by tutors;

- export to CSV or a web page;

- unique cross referencing - as you fill one timetable you automatically fill others.

\subsection{Kat Timetabler}

Kat Timetabler has both automatic optimisation and interactive timetabling capabilities. In manual mode it provides the scheduler with a wealth of information on class, teachers and room clashes as the lessons are assigned. The user may pause the optimisation process at any time and manually make changes to the timetable and then proceed with the calculation. The timetables can also be exported to HTML, Microsoft Excel and Microsoft Word, from which they can be viewed, printed or emailed to students and teachers.

Key Features:

- minimises the time required to prepare reliable timetables, thereby reducing the overall cost;

- powerful and user-friendly interactive interface;

- automatic, interactive and manual timetabling capabilities;

- in manual and interactive mode you can timetable the lessons by individual year, group, teacher, room, and subjects according to their difficulty to timetable;

- you can pre-assign lessons to specific periods of the week;

- day/period blocking and customised staggered lunch is possible;

- in manual and interactive mode it provides the user with all possible lesson moves; 
- can prepare two-weekly timetable cycles;

- fully customisable week-shape with different day lengths;

- groups from different years can be combined and linked;

- constructs timetables for individual room, teacher, and classes as well as the school master timetable;

- fully customisable printing and powerful reporting capabilities;

- detailed Users Manual and extensive tutorial style Help.

\subsection{S'CoolTime}

S'CoolTime $®$ for Windows is a user-friendly and efficient scheduling software program for secondary schools, universities, training centres etc. There is no limit regarding the number of courses, professors or teachers, subjects or classrooms. S' CoolTime ${ }^{\circledR}$ is developed and marketed by SRM Conseils.

Features:

- This software lets you position any course subject automatically in a schedule. To do so, it requires a minimum amount of information related to the subjects, times, professors and classrooms.

- The results generated can be modified, validated, assigned, printed and interfaced.

- Data is easily entered with help bubbles and on-line help.

- It is very simple and user-friendly.

- Its powerful calculation engine positions $100 \%$ of the subjects.

- Schedules can then be modified and validated at the user's convenience.

Advantages:

- You can configure your establishment, the working language, odd or even weeks, days, times, unit of time used (1 hour, $\frac{1}{2}$ hour, 20 minutes, $\frac{1}{4}$ or 5 minutes).

- Course starting times can be set at 5 minutes intervals. Working time limits can be easily configured for course time or teacher's profiles.

- Course subjects and/or classrooms can be linked with complex combinations. You can assign the teachers before or after the calculation.

- The processing will apply their profiles.

- S'CoolTime® allows user to rework his timetable in a few minutes until he is fully satisfied.

- You are still in control if you want to change the course time after the initial calculation. And even before, you can set the times you want.

- Data relating to: levels, sections, subjects, classrooms, teachers, and students are keyed in easily using an extremely user-friendly screen interface.

- Links: it is necessary to set up links between subjects and/or classrooms.

Example. One 8th grade section works with 2 groups of foreign language students. The first group contains students from another 8th grade section for English and the second group contains students from yet another 8th grade section for German. With S'CoolTime $\AA$ you can combine one or more subjects with one or more sections and define a linked number of hours. 


\subsection{TimeTabler}

Key Features:

- TimeTabler requires no knowledge of computers. It is designed to allow you to sit at the keyboard controls and 'drive' your way through the timetable.

- TimeTabler has been designed to ensure that you can emulate your normal timetabling method but with the speed of the computer. TimeTabler allows you to proceed in a way very similar to your usual manual method, while you remain in full control and can over-ride the machine at every stage.

- TimeTabler will help you to deal efficiently with:

$\circ$ the scheduling of part-time teachers,

o option patterns,

$\circ$ staggered lunch-breaks,

- split-site schools,

o shared teaching in older year-groups or the 'Sixth Form'.

- TimeTabler is totally self-checking. For example: it will never allow you to allocate by mistake any one teacher to two classes at the same time; it will always warn you if you begin to put two classes in the same room; or if you decide to put two separate lessons of Maths on the same day, etc. This means that the timetable is guaranteed to work when the new term starts.

- TimeTabler will automatically take care of all normal requirements like putting 5 periods of French on 5 different days (unless you tell it not to).

- Using the high speed of the computer, combined with efficient \& proven timetabling algorithms, TimeTabler looks ahead and shows you at every stage a recommended list of Priorities for you to consider. That is, it recommends which lesson you should place on the timetable, and where you should place it. At every stage, you can follow the program's advice or you can make your own decision. In this way you get the very best result of the computer's speed combined with your judgement \& experience $\&$ your knowledge of your colleagues.

- TimeTabler has a superb special feature called FIT. If a problem lesson will not fit into your timetable, then TimeTabler will quickly search through millions of complicated 'musical chairs' moves in order to find and show some solutions for you to choose from.

- Before you do your scheduling, you can use the Options program to sort out your students' optional or 'elective' choices in an efficient cost-effective way.

- After you have used TimeTabler, you can easily and quickly manage your daily Cover arrangements for absent staff using the StaffCover program.

- If you wish, you can transfer your timetable data quickly into SIMS-Nova-T, SIMS (STAR2 or STAR3), RM Integris, Phoenix, and other Admin systems, or spreadsheets, using the Export section of TimeTabler. 


\section{Tentative Comparison of Timetabling Software}

\subsection{MIMOSA}

The first stage - let's timetable using data from the real data from one of the colleges (.txt file). The schedule is created without any confines - it's allowable to consecutively add two equal subjects, the ultimate number of lessons per day is 10 , teachers are working without day offs. We only indicate the penalty points for gaps: 9 (maximum) for students and 5 for teachers.

The second stage - let's reduce maximum number of the lessons per day (9 lessons).

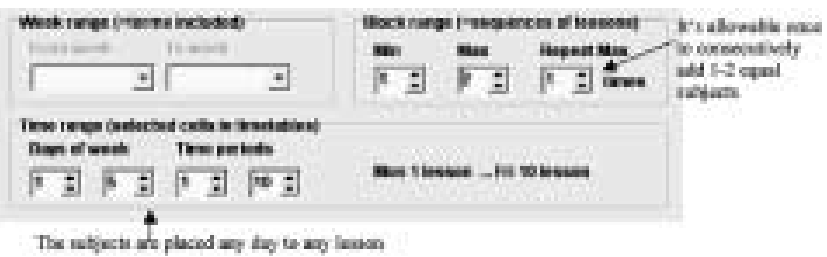

The statistics shows that the program has placed $93 \%$ of all subjects.

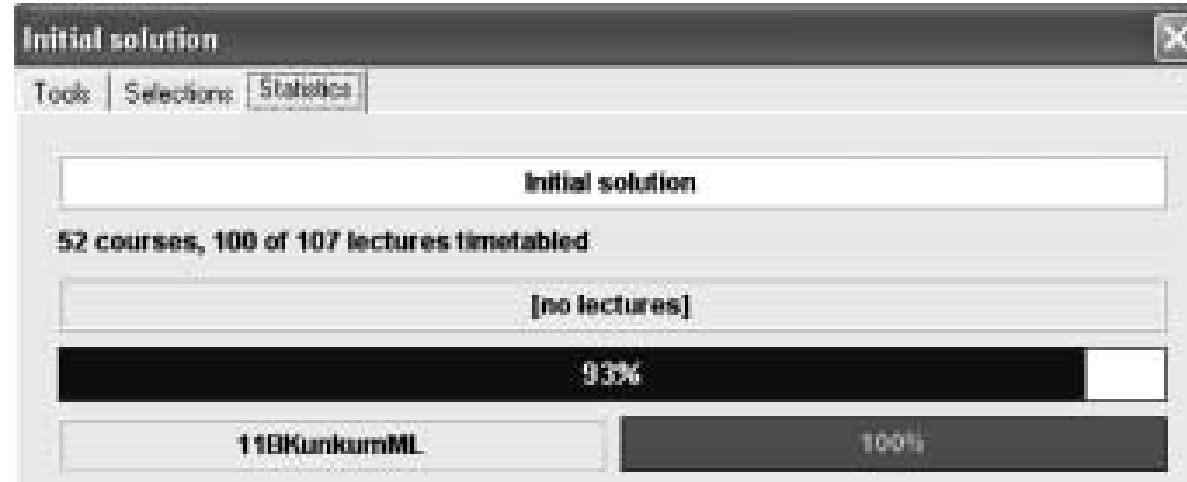

Now let's try to optimise the schedule: TOOLS/OPTIMISE. There are two algorithms for optimisation: one of them allows to come to second lesson and the other doesn't allow. Let's optimise by each of them:

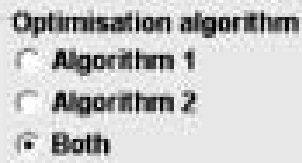


Let's indicate the penalty points for gaps:

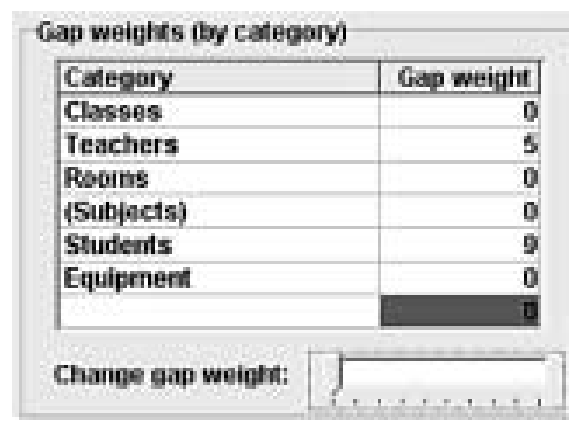

Only teachers' and students' gaps are important for us, therefore otherwhere we are writing " 0 ".

Not optimised schedule:

\begin{tabular}{|c|c|c|c|c|c|}
\hline & Mon & Tue & Wed & Thu & Fri \\
\hline 1 lesson & $\begin{array}{l}\text { 11Lietuv1DP } \\
\text { 11Lietuv2GL } \\
\text { 11Lietuv4NA } \\
-\end{array}$ & $\begin{array}{l}\text { 11Lietuv1DP } \\
\text { 11Lietuv2GL } \\
\text { 11Lietuv4NA } \\
-\end{array}$ & $\begin{array}{l}\text { 11Lietuv1DP } \\
\text { 11Lietuv2GL } \\
\text { 11BiolprdMD } \\
-\end{array}$ & $\begin{array}{l}\text { 11Lietuv1DP } \\
\text { 11Lietuv2GL } \\
- \\
-\end{array}$ & $\begin{array}{l}\text { 11Lietuv1DP } \\
\text { 11Lietuv4NA } \\
\text { 11GeogPolUI } \\
\text { 11PrdanglAM }\end{array}$ \\
\hline 2 lesson & $\begin{array}{l}\text { 11Lietuv1DP } \\
\text { 11Lietuv2GL } \\
\text { 11Lietuv4NA }\end{array}$ & $\begin{array}{l}\text { 11Dizteo2JN } \\
\text { 11Chemij2AR } \\
\text { 11MuzteorBJ }\end{array}$ & $\begin{array}{l}\text { 11Matema1GL } \\
\text { 11Matema3DJ } \\
\text { 11Matema2NL }\end{array}$ & $\begin{array}{l}\text { 11Matema3DJ } \\
\text { 11Matema2NL } \\
-\end{array}$ & $\begin{array}{l}\text { 11Etikaa1KJ } \\
\text { 11Angkb14JN } \\
-\end{array}$ \\
\hline 3 lesson & $\begin{array}{l}\text { 11Matema1GL } \\
\text { 11Matema2NL } \\
- \\
-\end{array}$ & $\begin{array}{l}\text { 11Matema1GL } \\
\text { 11Etikaa2KJ } \\
- \\
-\end{array}$ & $\begin{array}{l}\text { 11Matema3DJ } \\
\text { 11Matema2NL } \\
- \\
-\end{array}$ & $\begin{array}{l}\text { 11Angkb11KA } \\
11 \text { Angkb12SJ } \\
11 \text { Angkb14JN } \\
11 \text { Kompra2PV }\end{array}$ & $\begin{array}{l}\text { 11Matema1GL } \\
- \\
- \\
-\end{array}$ \\
\hline 4 lesson & $\begin{array}{l}\text { 11Angkb11KA } \\
\text { 11Angkb12SJ } \\
-\end{array}$ & $\begin{array}{l}\text { 11Angkb11KA } \\
\text { 11Angkb12SJ } \\
\text { 11Vokkb11JA }\end{array}$ & $\begin{array}{l}\text { 11 Angkb11KA } \\
\text { 11 Angkb13AM } \\
-\end{array}$ & $\begin{array}{l}\text { 11Angkb11KA } \\
\text { 11Angkb12SJ } \\
\text { 11Angkb14JN }\end{array}$ & $\begin{array}{l}\text { 11Matema1GL } \\
\text { 11IstPol1CL } \\
-\end{array}$ \\
\hline 5 lesson & $\begin{array}{l}\text { 11Biolog2MD } \\
- \\
-\end{array}$ & $\begin{array}{l}\text { 11Angkb13AM } \\
\text { 11Inform4ML } \\
\text { 11Vokkb11JA }\end{array}$ & $\begin{array}{l}\text { 11 Angkb13AM } \\
\text { 11PrdisanLR } \\
\text { - }\end{array}$ & $\begin{array}{l}\text { 11Biolog1MD } \\
- \\
-\end{array}$ & $\begin{array}{l}\text { 11Angkb13AM } \\
\text { 11FilosofCL } \\
-\end{array}$ \\
\hline 6 lesson & $\begin{array}{l}\text { 11BraizybNL } \\
\text { 11Ruskb21UN } \\
\text { 11Ruskb23MV }\end{array}$ & $\begin{array}{l}\text { 11Chemij3AR } \\
\text { 11Dizstu1JN } \\
\text { 11TeateorBR }\end{array}$ & $\begin{array}{l}\text { 11Lietuv3GI } \\
\text { 11Kompra1ML } \\
\text { - }\end{array}$ & $\begin{array}{l}\text { 11Biolog1MD } \\
- \\
-\end{array}$ & $\begin{array}{l}\text { 11Lietuv3GI } \\
- \\
-\end{array}$ \\
\hline 7 lesson & $\begin{array}{l}\text { 11Lietuv3GI } \\
\text { 11Ruskb21UN } \\
\text { 11Ruskb23MV }\end{array}$ & $\begin{array}{l}\text { 11Chemij3AR } \\
\text { 11Dizteo1JN } \\
\text { 11TeatstuBR }\end{array}$ & $\begin{array}{l}\text { 11Dizstu2JN } \\
\text { 11Chemij2AR } \\
-\end{array}$ & $\begin{array}{l}\text { 11Lietuv3GI } \\
\text { 11IstPol2LR } \\
-\end{array}$ & $\begin{array}{l}\text { 11Lietuv3GI } \\
- \\
-\end{array}$ \\
\hline 8 lesson & $\begin{array}{l}\text { 11Fizika2KS } \\
-\end{array}$ & $\begin{array}{l}\text { 11Fizika1LL } \\
-\end{array}$ & $\begin{array}{l}\text { 11Fizika3KS } \\
-\end{array}$ & $\begin{array}{l}\text { 11Fizika1LL } \\
\text { 11IstPol2LR }\end{array}$ & $\begin{array}{l}\text { 11Fizika2KS } \\
-\end{array}$ \\
\hline 9 lesson & $\begin{array}{l}\text { 11Fizika2KS } \\
-\end{array}$ & $\begin{array}{l}\text { 11Inform1PV } \\
\text { 11Chemij1AR }\end{array}$ & $\begin{array}{l}\text { 11Fizika3KS } \\
-\end{array}$ & $\begin{array}{l}\text { 11Fizika1LL } \\
-\end{array}$ & $\begin{array}{l}\text { 11Inform2ML } \\
\text { 11Inform3PV }\end{array}$ \\
\hline 10 lesson & 11InfprdaPA & $\begin{array}{l}\text { 11Inform1PV } \\
\text { 11Chemij1AR }\end{array}$ & 11Ruskb22KS & 11IstPol3GR & $\begin{array}{l}\text { 11Inform2ML } \\
-\end{array}$ \\
\hline
\end{tabular}


Optimisation had reduced the number of gaps, but the programme has not placed all the subjects.

\section{Optimise timotables}

52 courses, 100 of 107 lectures timotabled

Block length range 1 - 2 time units

$93 \%$

Iime: 00:00:57, Changes: 45+103-148, Changeshin: 155,27 (5.4.1)

Optimised schedule:

\begin{tabular}{|c|c|c|c|c|c|}
\hline & Mon & Tue & Wed & Thu & Fri \\
\hline \multirow[t]{3}{*}{1 lesson } & 11Lietuv1DP & 11Lietuv1DP & 11Lietuv1DP & 11Lietuv1DP & 11Lietuv1DP \\
\hline & 11Lietuv2GL & 11Lietuv2GL & 11Lietuv2GL & 11Lietuv2GL & 11Lietuv4NA \\
\hline & 11Lietuv4NA & 11Lietuv4NA & - & - & - \\
\hline \multirow[t]{3}{*}{2 lesson } & 11Lietuv1DP & 11Dizstu2JN & 11Matema1GL & 11Matema3DJ & 11Angkb14JN \\
\hline & 11Lietuv2GL & 11Chemij2AR & 11Matema3DJ & 11Matema2NL & 11Biolog2MD \\
\hline & 11Lietuv4NA & - & 11Matema2NL & - & - \\
\hline \multirow[t]{4}{*}{3 lesson } & 11Matema1GL & 11Matema1GL & 11Matema3DJ & 11Angkb11KA & 11Matema1GL \\
\hline & 11Matema2NL & 11Etikaa2KJ & 11Matema2NL & 11Angkb12SJ & - \\
\hline & - & - & - & 11Angkb14JN & - \\
\hline & - & - & - & 11 Kompra2PV & - \\
\hline \multirow[t]{3}{*}{4 lesson } & 11Angkb11KA & 11Angkb11KA & 11Angkb11KA & 11Angkb11KA & 11Matema1GL \\
\hline & 11Angkb12SJ & 11Angkb12SJ & 11Angkb13AM & 11Angkb12SJ & 11IstPol1CL \\
\hline & - & 11 Vokkb11JA & 11PrdanglAM & 11Angkb14JN & - \\
\hline \multirow[t]{3}{*}{5 lesson } & 11GeogPolUI & 11Angkb13AM & 11Angkb13AM & 11Biolog1MD & 11Angkb13AM \\
\hline & 11Inform4ML & 11Kompra1ML & 11FilosofCL & - & 11MuzteorBJ \\
\hline & 11IstPol3GR & 11Vokkb11JA & - & - & - \\
\hline \multirow[t]{4}{*}{6 lesson } & 11BiolprdMD & 11Chemij3AR & 11Lietuv3GI & 11Biolog1MD & 11Lietuv3GI \\
\hline & 11Chemij2AR & 11Dizstu1JN & 11PrdisanLR & - & - \\
\hline & 11Ruskb21UN & 11TeateorBR & - & - & - \\
\hline & 11Ruskb23MV & - & - & - & - \\
\hline \multirow[t]{3}{*}{7 lesson } & 11Lietuv3GI & 11Chemij3AR & 11Dizteo2JN & 11Lietuv3GI & 11Lietuv3GI \\
\hline & 11Ruskb21UN & 11Dizteo1JN & 11InfprdaPA & 11IstPol2LR & - \\
\hline & 11Ruskb23MV & 11TeatstuBR & - & - & - \\
\hline \multirow[t]{2}{*}{8 lesson } & 11Fizika2KS & 11Fizika1LL & 11Fizika3KS & 11Fizika1LL & 11Fizika2KS \\
\hline & - & - & - & 11IstPol2LR & - \\
\hline \multirow[t]{2}{*}{9 lesson } & 11Fizika2KS & 11Inform1PV & 11Fizika3KS & 11Fizika1LL & 11Inform2ML \\
\hline & - & 11Chemij1AR & - & - & 11Inform3PV \\
\hline \multirow[t]{2}{*}{10 lesson } & 11Ruskb22KS & 11Inform1PV & 11Etikaa1KJ & 11BraizybNL & 11Inform2ML \\
\hline & - & 11Chemij1AR & - & - & - \\
\hline
\end{tabular}


One student's schedule before and after the optimisation:

\begin{tabular}{|c|c|c|c|c|c|}
\hline \multirow{3}{*}{$\begin{array}{l}\text { 11 Juozapri } \\
\text { t lesson }\end{array}$} & \multicolumn{2}{|c|}{ 11602are? } & \multirow[t]{2}{*}{ P te } & & \multirow[b]{2}{*}{$\mathrm{Fri}$} \\
\hline & Mon & Tue & & Thu & \\
\hline & - $[14]$ & - I.10 & [-क] & {$[-4]$} & 항 \\
\hline 2 lesson & - $[-14]$ & 11Chempar & 11Matema?l & fromatemazul & 114iolog?s: \\
\hline 3 lesson & 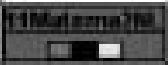 & 을 & 14Matematit & E [-24] & $=|-14|$ \\
\hline 4 lesson & e [-15] & 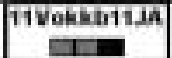 & - $\mid-1 a]$ & $\Leftrightarrow\lfloor-15]$ & - $|-14|$ \\
\hline 5 lesson & 11CieogPeda & 11Vohib11sa & - I-13 & $6 \mid 1 x$ & 하 \\
\hline 6 lesson & 11Chemil2AR & 110irstut.II & 11Lietursa & - $\mid-13]$ & t1Letuvial \\
\hline 7 lesson & 12Lietumba & 110izteo1.ji & 11infiprdaen & 11Lietuv3Gi & 11Lietuyjar \\
\hline Blesson & $\begin{array}{c}\text { 1tfinkazks } \\
\text { cang }\end{array}$ & {$[-6]$} & 하 & 인 & $\begin{array}{c}\text { 11Fiziharks } \\
\text { a }\end{array}$ \\
\hline 9 lesson & $\begin{array}{c}\text { 11Fizikazks } \\
\text { e }\end{array}$ & $\begin{array}{c}\text { 11informipV } \\
\end{array}$ & 하 & e & $=\mid \cdot 1 \pi$ \\
\hline 16 lesson & e $|-2|$ & $\begin{array}{c}\text { 11informipV } \\
\square\end{array}$ & 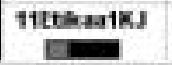 & $\begin{array}{c}\text { 11Eraizytiul } \\
\text { Ea }\end{array}$ & - $|-11|$ \\
\hline e.coof & WEME & & - S4M ROA & IF WNKS LFE & \\
\hline
\end{tabular}

\begin{tabular}{|c|c|c|c|c|c|}
\hline 78 & 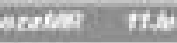 & arats? & for & & $=t$ \\
\hline \multirow{2}{*}{ thasorites } & Mon & Tue & Wed & The & \multirow{2}{*}{$\frac{\mathrm{fri}}{11 \mathrm{Gees} P \mathrm{olui}}$} \\
\hline & e $\{.14\}$ & $|-14|$ & $(-46)$ & e & \\
\hline 2 lesson & - $[-14]$ & 11ChemijzAR & 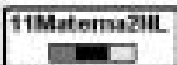 & 11Matema2fil & 11ttikask \\
\hline 3 lesson & 119atema?il & {$[-20]$} & 119atemaZiL. & $\mid-24]$ & e $|-14|$ \\
\hline 4 lesson & $\approx[-15]$ & 1tVokhbitida & $\Leftrightarrow \quad[-15]$ & {$[-19]$} & {$[-14]$} \\
\hline 5 lesson & 11BiologamD & 11VokkbituA & [-45] & {$[-13]$} & [-1]] \\
\hline 6 lesson & 11 ilakirybill. & Tinizstirtmini & 1tLietumaG & {$[.43]$} & T1Liehurial \\
\hline$T$ leseon & 11LieturaG & $\begin{array}{c}110 i z t e 01 \\
\text { and }\end{array}$ & 11Chemizan & 11Letuv3ar & 11LieturjG \\
\hline 8 lesson & 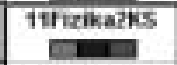 & 은 & e & $|-12|$ & 14firika?ks \\
\hline 5 lesson & 14Fuikalks & TitrifermipV & 은 & {$[-5]$} & {$[-17]$} \\
\hline to lesson & $\begin{array}{c}11 \text { Mofprdaph } \\
\text { Ene }\end{array}$ & $\begin{array}{c}\text { 11informs } \\
\text { per }\end{array}$ & 6 & 은 & 요 \\
\hline & HENE. & 2 & 284 DRTE & 5 IAI & \\
\hline tallatsin & g7 nates: & 621 & Q & Wenicto & \\
\hline
\end{tabular}

The schedule has been improved visibly but nevertheless there is a number of gaps and unplaced subjects. Let's write unplaced subjects into the yellow field: LEFT $+2 \mathrm{~h}$ - it means that there are two subjects' hours unplaced. The red mark means that it's impossible to place the subject into this field, and the number in brackets with mark "-" 
means the number of components (teachers, classrooms, students) contradict with this subject's placement into this field.

MIMOSA has not placed all the subjects without any confines, therefore it has "relapsed" in the first stage.

\section{The advantages of the program:}

- The considerable advantage is the possibility to view any teacher's and any student's individual schedule. If somebody fails to schedule automatically it's very convenient to schedule manually with MIMOSA by choosing every student separately.

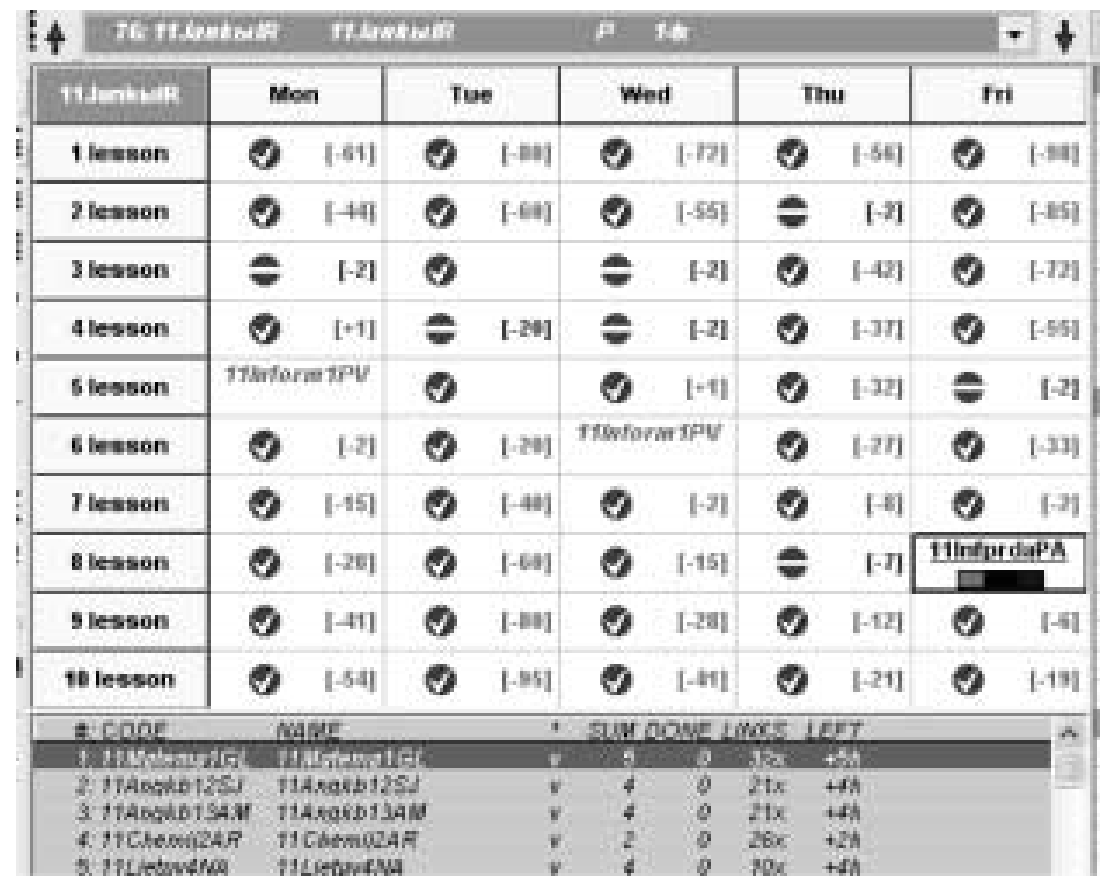

The picture shows us that we can place the chosen subject into green field, numbers with mark "+" show the number of components for which the field will be deleted, numbers with mark "-" show the number of components for which the field will appear. We can't place any subject into red fields because it contradicts with the determinations, i.e., at the moment teacher or students has the lesson already, or it's indicated in the programme that at the moment concrete subject lesson is impossible.

- One more MIMOSA advantage is well-organised data import/export from the other programmes (for example MS Excel, Clipboard and similar). 
- It's possible to indicate what days and even lessons have to be free for him (marked with red hyphens):

\begin{tabular}{|c|c|c|c|c|c|c|}
\hline IEFD & & & 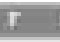 & & & 4 \\
\hline Mits & now & Tus & wed & The & fat & \\
\hline thensum & 0 & 20 & 0 & (9) $[-1]$ & N1 & \\
\hline phesens & $\theta$ & $a r$ & $\theta$ & ( & w & \\
\hline Ileasus & 0 & का & 0 & 0 & & \\
\hline Alesens & 0 & wi & 0 & का & 9 & \\
\hline Sheasum & 0 & an & 0 & at & $\mathbb{1}$ & $\mathrm{H}-\mathrm{H}$ \\
\hline Anoses: & 0 & an & 0 & $\omega$ & 0 & H \\
\hline Thenesen & 0 & ar & 0 & as & 0 & I \\
\hline Imserm & 0 & wir & 0 & $\theta$ & 0 & 1.4 \\
\hline glensum & $\theta$ & aw & $\theta$ & a 101 & 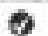 & I-8 \\
\hline Wlesesn & 0 & or & 0 & $\theta \quad \|$ & 0 & 16 \\
\hline
\end{tabular}

3.2. IMI Timetable

\begin{tabular}{|c|c|}
\hline \multicolumn{2}{|l|}{ History } \\
\hline "Profiled school" applet version & 2001 \\
\hline \multicolumn{2}{|c|}{ 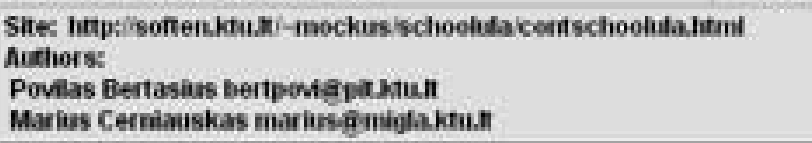 } \\
\hline "Profiled school" servet version & 2001 \\
\hline \multicolumn{2}{|l|}{ 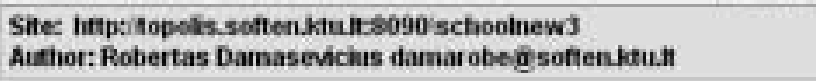 } \\
\hline "Piofiled school" JSP 1.2 with CustomTags version & 2002 \\
\hline \multicolumn{2}{|l|}{$\begin{array}{l}\text { Sitec this ste } \\
\text { Author: Wytaitas Germanimiclas wyis abonamens.cem }\end{array}$} \\
\hline "Proflled schoor" JSP 1.3 with Custom Taes version & 2003 \\
\hline
\end{tabular}

IMI timetable at the first stage had placed all the subjects.

Not optimised schedule: 


\begin{tabular}{|c|c|c|c|c|}
\hline $20=$ & Hancese & Ansuse & Buset & $A=n=$ \\
\hline 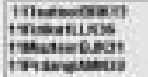 & 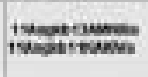 & 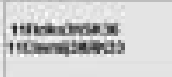 & 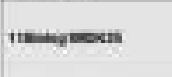 &  \\
\hline 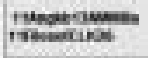 & 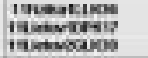 & 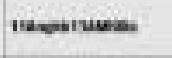 & 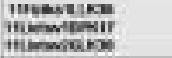 & 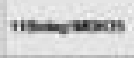 \\
\hline 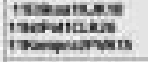 & 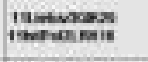 & 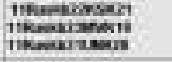 & 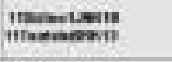 & 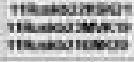 \\
\hline 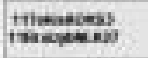 & 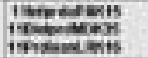 & 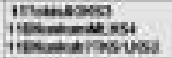 & 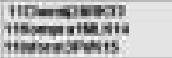 &  \\
\hline Romecosesa & iseinasavis & 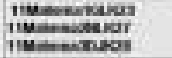 & 1msenumass: & 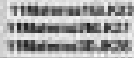 \\
\hline trobahregen & 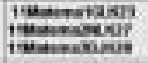 & Howamex & 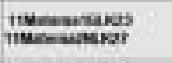 & 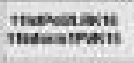 \\
\hline 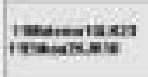 & 170hanesos & 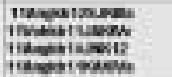 & 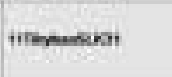 & 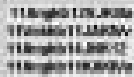 \\
\hline 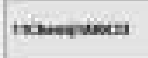 & 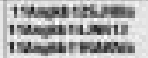 & 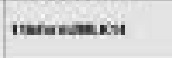 & 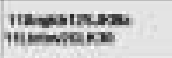 & madsarement \\
\hline 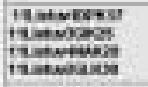 & ixenowers & 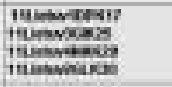 & nowasemsyaz & 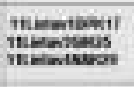 \\
\hline 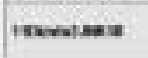 & 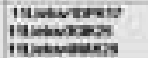 & & 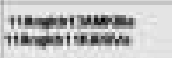 & \\
\hline
\end{tabular}

Now let's try to optimise it by indicating similar gaps penalty points and permitting 10 lessons per day:

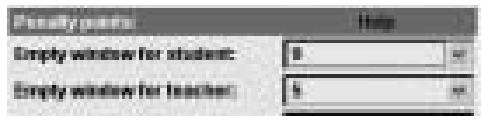

The optimised schedule:

\begin{tabular}{|c|c|c|c|c|}
\hline rosen & Gave & | & menters & 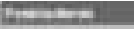 \\
\hline mearturas & 1moatzues: & Wonements & nanderaseds & ntiansosese \\
\hline 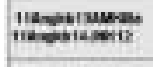 & 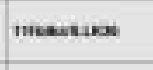 & 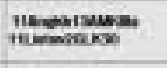 & 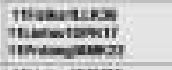 & niand wordi \\
\hline 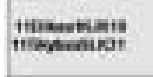 & 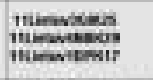 & 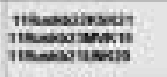 & 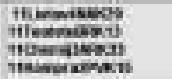 & 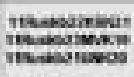 \\
\hline 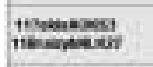 & 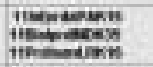 & 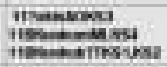 & 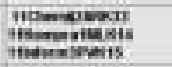 & 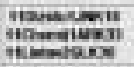 \\
\hline Mrnesiesen & 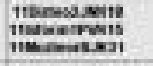 & 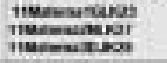 & 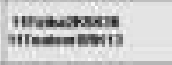 &  \\
\hline 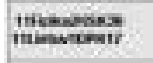 & 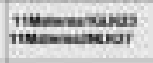 & 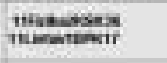 & 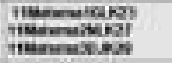 & 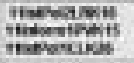 \\
\hline 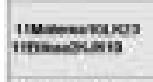 & inowases & 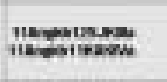 & 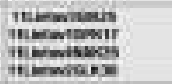 & 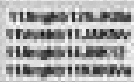 \\
\hline 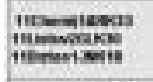 & 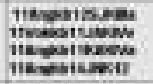 & Midmaiken & 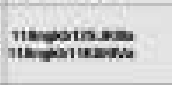 & Hedirelue sid \\
\hline 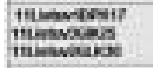 & Moneratent & minmocies & 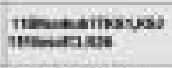 & Mimatous \\
\hline 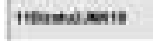 & & & 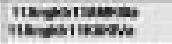 & \\
\hline
\end{tabular}


Let's look at any student's schedules before and after the optimisation:

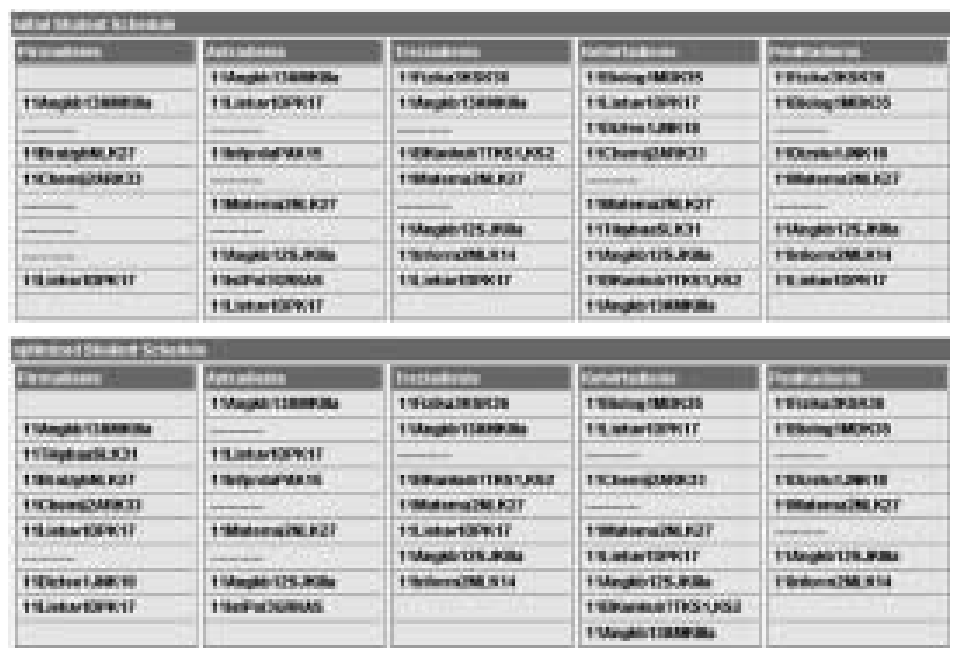

We'll notice that the number of gaps has been reduced.

The second stage is reducing the number of lessons till 9 per day.

\begin{tabular}{|c|c|c|c|c|}
\hline 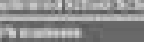 & Ginger & 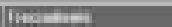 & Totiten & senters \\
\hline & 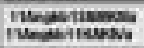 & Rowiswedi & renesenos & 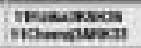 \\
\hline thenowiens: & $\begin{array}{l}\text { Trosatiles } \\
\text { rungavieness }\end{array}$ & 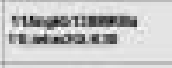 &  & 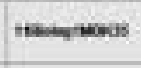 \\
\hline 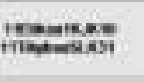 &  & $\begin{array}{l}\text { Chotagenest } \\
\text { thistain: }\end{array}$ &  & 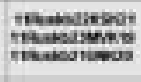 \\
\hline $\begin{array}{l}\text { Imanaress } \\
\text { inowiver }\end{array}$ & 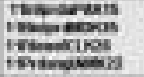 & 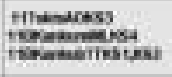 &  & 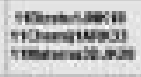 \\
\hline 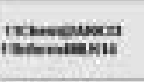 & 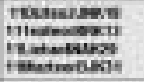 & 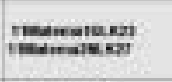 & 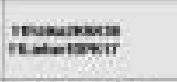 & 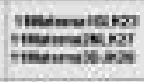 \\
\hline 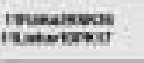 & Reveriukn & Bumaresas & 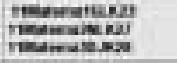 & 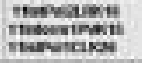 \\
\hline 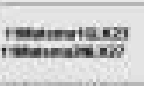 & 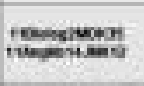 & 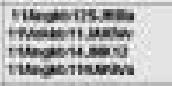 & 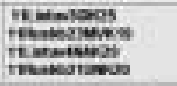 & 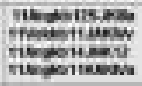 \\
\hline 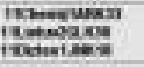 & 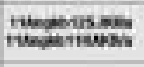 & 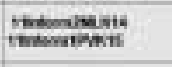 & 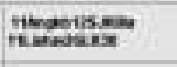 & thesmesesia \\
\hline 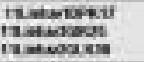 & 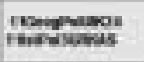 & 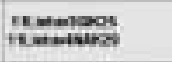 & 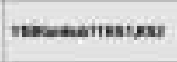 & TEmentuat \\
\hline
\end{tabular}

The program has not placed 2 subjects. The disadvantage of the program - there is no note that all subjects are not placed. If we would increase the number of the lessons per day till 10, we could see missing subjects which are placed into tenth lessons. We can come to a conclusion that the program distributes the subjects across all 10 lessons and then cuts them till the number indicated in settings: 


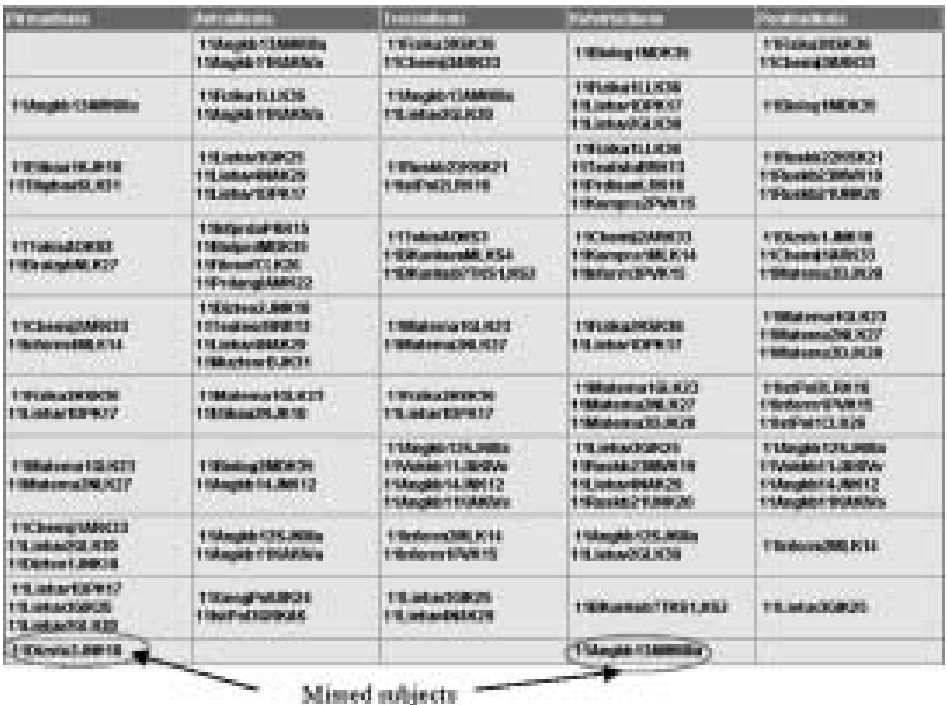

\section{The advantages of the program:}

- the program allows to see individual timetables of any teacher and student and to see not-optimised and optimised timetables together, which makes it possible to compare them;

- every time when we run the program with the same input data, it generates and optimise new timetable, that's why it is possible to select the acceptable version.

\section{The means of development of the program in the future:}

1) to make input more available and flexible for the ordinary user with the help of spreadsheet;

2) to design the possibility to plan ahead four free days for teachers (they have only two at the moment) because there are teachers for which this work is avocation;

3) to design the possibility to export the timetable in order to make it possible to improve it manually;

4) to design the possibility to schedule integrated subjects (when several teachers teach one and the same subject).

\section{3. aSc Timetables}

This program has successfully accomplished first two stages - placed all the subjects.

This program more fits traditional scheduling for classes but not for students, therefore it's difficult to show the finished timetable because we can 't show separate student's timetable in it, but only the whole class. In the case when not all class but only a part attends some subject, there is made this subject's seminar and participants are indicated. Then in order to see his own timetable every student has to prescribe the seminars which he attends and to look for these seminars in common class timetable. It's very inconve- 
nient because while scheduling we don't see how many windows has every student and therefore we can't reduce them manually.

The timetable looks as follows:

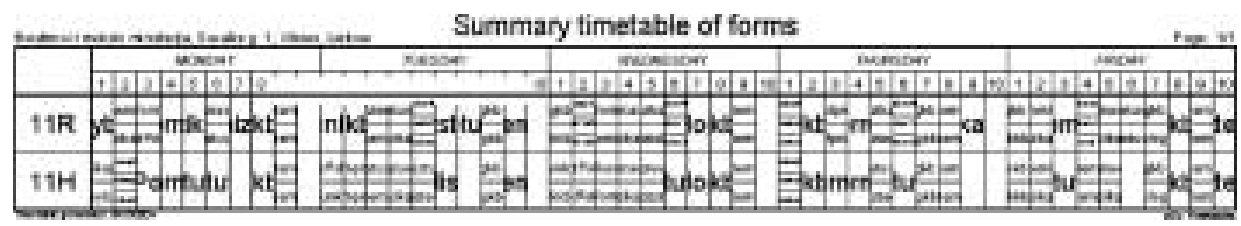

On the other hand, this program fits school details. It's possible to estimate free hours for every teacher as well as hours which could be booked only when there is no other way:
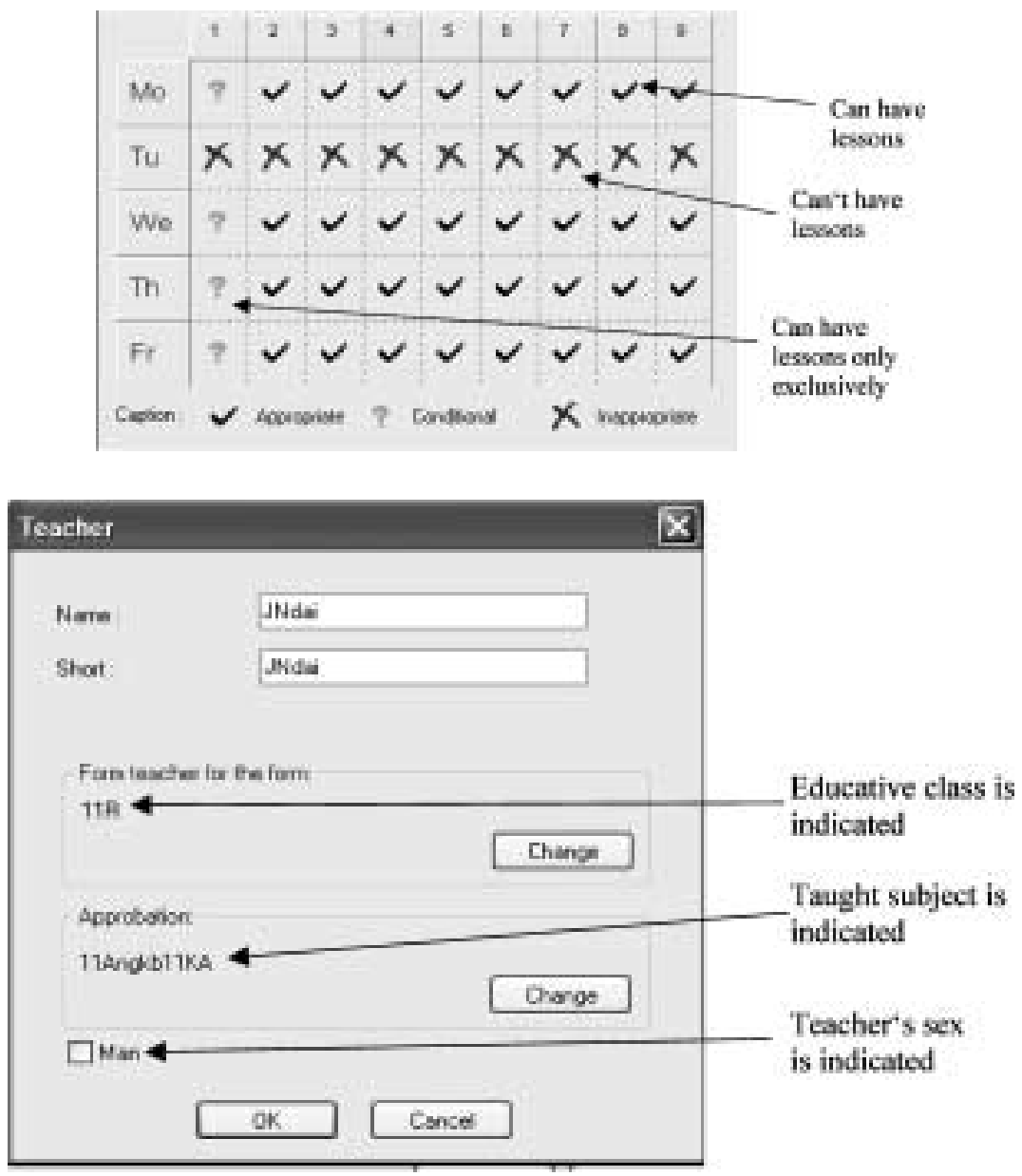


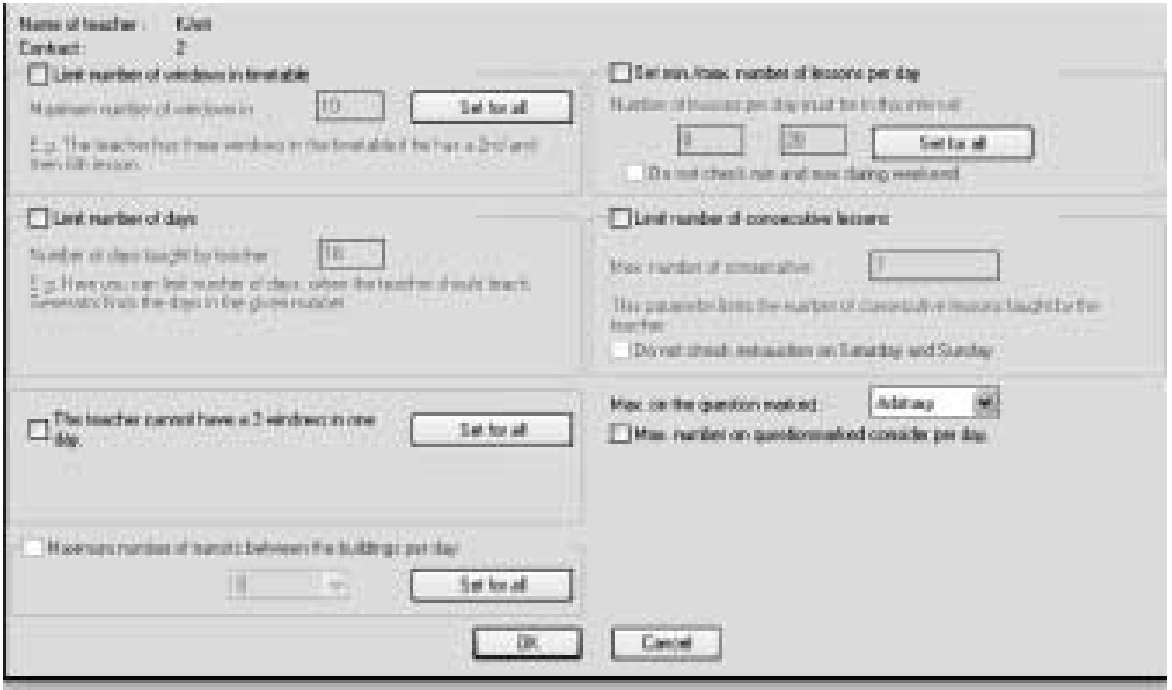

The advantages of the program:

1) limitation of windows in the timetable;

2) limitation of working days - if teacher has to work only few days and it's unimportant which ones, the number of his working days is indicated;

3 ) the number of possible windows for teacher per day is indicated;

4) the number of lessons for teacher per day is settled;

5) the number of consecutive lessons for teacher is indicated;

6) ultimate number of lessons for teachers which they can have during questionmarked time is indicated;

7) there is the possibility to allow the class to come to the second lesson;

8) the class mentor is indicated;

9) there is the possibility to indicate lunch breaks, etc.;

10) if it is not possible to create a schedule, the program contains a set of testing tools which can help you isolate your problem, whether it be a mistake inputting data or restraints that are too constrictive;

11) you can also make some changes in timetables manually;

12) print support ranges from printing big summary timetable which you can put on your school's notice board;

13) you can export timetables to MS Excel or HTML for publishing on your school's web site or intranet.

There was made an attempt to schedule the real profiled secondary school's timetable. Even without any limitations for teachers (that is without free days) the program hasn't placed all the subjects because it considers class as a minimal unit. There appear such cases when all the class has a window but it's impossible to place any subject into this window: 


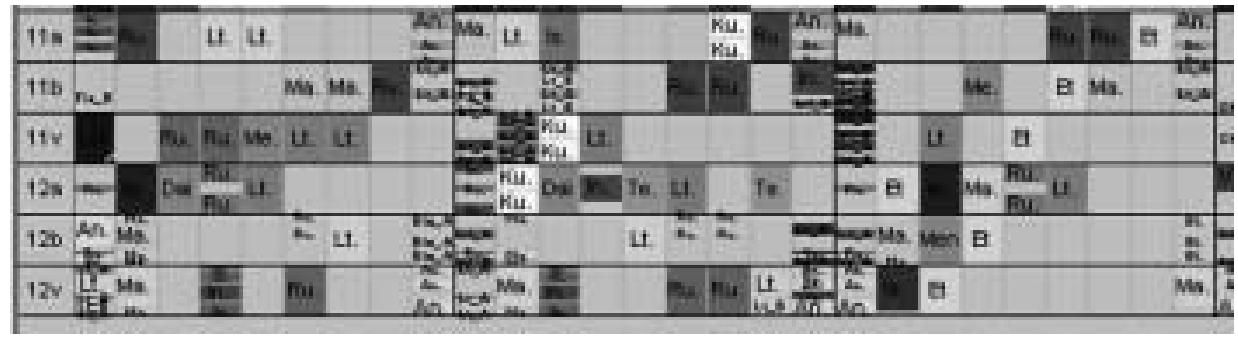

\section{Conclusions}

\section{MIMOSA:}

The program had not placed all the subjects without any confines, therefore it has "relapsed" from comparison already in the first stage.

Main advantages:

- the possibility to view any teacher's and any student's individual schedule. If somebody fails to schedule automatically it's very convenient to schedule manually with MIMOSA by choosing every student separately;

- well-organised data import/export from the other programmes (for example MS Excel, Clipboard and similar);

- the possibility to indicate what days and even lessons have to be free for him.

\section{aSc Timetables:}

The program had successfully accomplished first two stages - placed all the subjects. The program more fits traditional scheduling for classes but not for students.

Main advantages:

- limitation of windows in the timetable;

- limitation of working days - if teacher has to work only few days and it's unimportant which ones, the number of his working days is indicated;

- the number of possible windows for teacher per day is indicated;

- the number of lessons for teacher per day is settled;

- the number of consecutive lessons for teacher is indicated;

- ultimate number of lessons for teachers which they can have during questionmarked time is indicated;

- there is the possibility to allow the class to come to the second lesson;

- the class mentor is indicated;

- there is the possibility to indicate lunch breaks, etc.;

- if it is not possible to create a schedule, the program contains a set of testing tools which can help you isolate your problem, whether it be a mistake inputting data or restraints that are too constrictive;

- you can also make some changes in timetables manually;

- print support ranges from printing big summary timetable which you can put on your school's notice board; 
- you can export timetables to MS Excel or HTML for publishing on your school's web site or intranet.

There result of scheduling the real profiled secondary school's timetable:

- even without any limitations for teachers (that is without free days) the program hasn 't placed all the subjects because it considers class as a minimal unit;

- there appear such cases when all the class has a window but it's impossible to place any subject into this window.

\section{IMI Timetable:}

The trials of this program had showed better results if compared with commercial programs MIMOSA and aSc Timetables.

Main advantages:

- the program allows to see individual timetables of any teacher and student and to see not-optimised and optimised timetables together, which makes it possible to compare them;

- every time when we run the program with the same input data, it generates and optimise new timetable, that's why it is possible to select the acceptable version.

The means of development of the program in the future:

- to make input more available and flexible for the ordinary user with the help of spreadsheet;

- to design the possibility to plan ahead four free days for teachers (they have only two at the moment) because there are teachers for which this work is avocation;

- to design the possibility to export the timetable in order to make it possible to improve it manually;

- to design the possibility to schedule integrated subjects (when several teachers teach one and the same subject).

\section{References}

Mockus, J. (2000). A Set of Examples of Global and Discrete Optimization: Application of Bayesian Heuristic Approach. Kluwer Academic Publishers.

Mockus, J. A Set of Examples of Global and Discrete Optimization 2: Home Work for Graduate Students. http://soften.ktu.lt/ mockus/

ActiveTimetable 2003. http: / / www . activesoft.biz/

aSc TimeTables. http: //www. asctimetables.com/

CMIS Scheduler (CCM). http: //www. facility. ie/frames/fsch1H.htm

Cyber-Matrix Class Scheduler. http: //www. cyber-matrix.com/csched.html

iMagic. http: //www.imagictimetablesoftware.com/

Kat Timetabler. http: //www.scisoft-kat.com/

Mimosa. http: //www.mimosasoftware.com/

S'CoolTime. http://www.srm-conseil.com/uk/presentation.html

TimeTabler. http://www.timetabler.com/ 
R. Gaidukevičienė has completed basic studies in mathematics and informatics provided by Vilnius Pedagogical University in 2001 and was awarded the degree of a bachelor of mathematics and teacher's qualification. In 2003 she has completed postgraduate studies at Vilnius Pedagogical University and was awarded the degree of a master of informatics. R. Gaidukevičienè has been working as a teacher of informatics (information technologies) at Vilnius "Senamiesčio" Secondary School since 2001. She was awarded the qualification of senior teacher of information technologies in 2003. She is $\mathrm{PhD}$ student of informatics engineering at the Faculty of Mathematics and Informatics in Vilnius Gediminas Technical University since 2003. Her present research object is analysis of profiled school scheduling optimization problem.

E. Kurilovas has graduated from the Vilnius University as the specialist in the applications of mathematics and obtained the degree of master of mathematics and informatics in 1986. Since 2001 he is a head of the Projects Division of the Centre for Information Technologies in Education under the Ministry of Education and Science of the Republic of Lithuania. He is in charge of organization of international co-operation, preparation of projects of national significance and performance of scientific research on ICT implementation in education. E. Kurilovas has participated in preparation of several Lithuanian strategic documents on ICT implementation in education. He also works as consultant and expert-evaluator of projects of PHARE and Leonardo da Vinci programmes as well as European Structural Funds. He is PhD student of informatics engineering in Institute of Mathematics and Informatics and Vilnius Gediminas Technical University since 2003. His present research object is analysis of virtual learning environments for students with special educational needs.

\section{Profiliuotos mokyklos tvarkaraščio optimizavimo programu lyginamasis tyrimas Lietuvoje}

\section{Rita GAIDUKEVIČIENĖ, Eugenijus KURILOVAS}

Spresti optimalaus mokyklos tvarkaraščio sudarymo problemą yra labai svarbu mokyklos darbo efektyvumo didinimui. Užduotis yra sudaryti patogiausią tvarkarašti iš visu galimų. Visi nepatogumai yra vertinami baudos taškais.

Šio tyrimo tikslas yra išanalizuoti optimizavimo atžvilgiu keletą Lietuvoje paplitusių komerciniu mokyklos tvarkaraščio sudarymo programu bei palyginti jas su šiuo metu veikiančia Matematikos ir informatikos instituto (MII) Optimizavimo skyriaus programa. Mūsų tyrimo objektas yra šiu programų optimizavimo algoritmų kokybės tyrimas ir palyginimas.

Vienas uždaviniu yra nustatyti esamas rinkoje mokyklos tvarkaraščio sudarymo programas, kurios tiktų Lietuvos profiliuotoms mokykloms.

Kitas uždavinys yra MIMOSA, aSc Timetables ir MII tvarkaraščio sudarymo programų tyrimas ir eksperimentinis palyginimas optimizavimo atžvilgiu.

Programų tyrimą vykdème trimis etapais:

1) tvarkaraštis sudaromas be apribojimu, t.y. leidžiama sudèti iš eilès du vienodus dalykus, maksimalus pamoku skaičius per dieną - 10, mokytojai dirba be laisvų dienų;

2) maksimalus pamokų skaičius per dieną sumažinamas iki 9;

3) realios Vilniaus vidurinès mokyklos tvarkaraščio sudarymas ir optimizavimas. 